\title{
Exploring the Critical Influencing Factors of Customer Satisfaction in Telecommunication Sector in Bangladesh
}

\author{
Dhanonjoy Kumar ${ }^{1^{*}}$, Ahasanul Haque ${ }^{2}$, Pranam Dhar ${ }^{3}$ \\ ${ }^{1}$ Department of Management, Islamic University, Kushtia, Bangladesh-7003 \\ ${ }^{2}$ Department of Business Administration, International Islamic University Malaysia Box No. 10, 50728, Kuala \\ Lumpur, Malaysia \\ ${ }^{3}$ Department of Commerce \& Management, West Bengal State University, Kolkata-700126, West Bengal, India. \\ *Correspondence E-mail:dhanonjoykumarsaha@gmail.com
}

\begin{abstract}
Telecommunication sector has a great importance for the socio-economic development of a country, and it is immeasurable. In the competitive market, telecommunication sector ensures customer satisfaction and customer's pivotal attention greatly. The major aims of this study are to know about the degree of customer satisfaction in Bangladesh and to find out its significance factors such as organizational efficiency, organizational competency, service- quality and product price. To achieve these objectives, primary and secondary data have been used. For collecting primary data, Simple random sampling technique has been used and 400-questionnaire was surveyed. Statistical Package for Social Science (SPSS) and Smart PLS 3.2.3 technique was used for analysing the data. The study found that old age and illiterate personality has no feelings and thinking about service offer, price, internet facilities etc. They want good network and talk time service. But educated personality and young age people are very conscious about talk time, network, service quality, internet facility, product offers etc. The study also revealed that organizational competency and organizational efficiency of the organization has no effect on customer satisfaction. The study also finds out that product price and service quality have a significant impact on customer satisfaction of telecom sector in Bangladesh.
\end{abstract}

Keywords:Customer Satisfaction; Organizational Efficiency; Organizational Competency; Service Quality; Connectivity and Network

\section{Introduction}

Customers become satisfied when a company fills up the demands of customers' expectation by supplying products and services properly (Farris et al., 2010). Literature on customer satisfaction explains the consumer is the king of marketing and the single most important factor in determining a company's success (Mouri, 2005). The mobile sectors are developing rapidly, in this country. Grameenphone Limited has 74.361 subscribers, Robi Axita Limited has 48.843, Banglalink Digital Communications Limited has 34.876 subscribers, and Teletalk Bangladesh Limited has 4,840 subscribers, according to UNB (Dhaka Tribune, June 19, 2020). According to data released by the Bangladesh Telecommunication Regulatory Commission in March, Bangladesh now has over 100 million internet subscribers (BTRC, 2020). The mobile users use mobiles not only for making a call but also for getting different add-on services like SMS, video-calling, money-related services, social insurance services, entertainment, web-based shopping 
apps, and web perusing. The Telecom industry plays important roles for developing of this country and the government is trying her best for enriching these industries (Uddin et al., 2014). Now, it is high time to measure the customers' satisfaction level in this sector because only a satisfied client may explain his/her positive emotional state for stabilizing the firm. So, this paper synthesizes the existing literature on customer satisfaction and identifies some key requisites that must be considered during the development of future mobile operator's strategies.

\section{Review of Literature:}

The ultimate objective of company is customer loyalty. Customer satisfaction is primarily determined by the quality of services provided (Agbor, 2011). According to Alam et al., (2020), service quality has an indirect impact on Gen $Y$ consumer loyalty toward superstores, with corporate image playing a role. System quality, knowledge quality, eservice quality, and perceived value all had a positive and important impact on online loyalty, according to Putri \& Pujani (2019). A study of Nurysh et al., (2019) analyzed the significant factors, for example, perceived value and service quality that can legitimately influence consumer loyalty in Malaysian mobile phone service provider. The moderating effect of engaging quality of options has also been tested across variables. Durdyev et al., (2018) used a structural equation modeling technique that used a partial least square approach (PLS-SEM). The results of the PLS-SEM showed that clients' potential behavioral intentions are affected by their satisfaction with construction companies' service excellence. Bala et al., (2018) showed that network coverage, internet offer, tariff offer are the fundamental factors for influencing client which assists withholding the client and to make client dependability. Rizomyliotis et al., (2018) examined the concurrent impact of apparent service quality, perceived value, consumer loyalty, and trust in client faithfulness. The outcomes of every variable had a noteworthy constructive outcome on loyalty, except perceived value. Customer satisfaction was found to be important in evaluating the contribution of exogenous constructs to the R2 value of endogenous constructs by Irfan et al., (2016) (f $2>0.35$ ). Yeo et al., (2015) investigated it using Smart PLS 3.2.1 software, partial least squares structural equation modeling (PLS-SEM) was used to validate the $P S Q$ dimensions and investigate their relationship with customer satisfaction. PSQ is discovered to be a five-factor construct with major positive effects on customer satisfaction in terms of management, image, and social responsibility.

Organizational Efficiency- Organizational efficiency contributes greatly on customer satisfaction. Kumar et al., (2020) showed that there is a noteworthy relationship between consumer loyalty and service quality. Danish et al., (2015) elaborated that trust, bliss, and devotion client retention has been expanded. Consumers repurchase intention expands when they are happy with definite products and services and are getting enthusiastic and functional advantages. Customer satisfaction is influenced by network quality, price (overall charge), promotional offer, availability of customer service center, value added service, and speed (Hossain et al., 2016). Customers' values are a significant driver of customer satisfaction, according to Hossainet al., (2012). Customers are dissatisfied for a variety of reasons, according to the report, including the quality of airtime, helpline service, information center service, high billing rate, and so on. Customer satisfaction is linked to brand image, service quality, and price, according to Malik, Ghafoor, and lqbal (2012). Customer satisfaction was correlated with higher levels of call efficiency, value-added services, and customer care, according to Kim et al., (2004), while price structure, mobile device, and procedure convenience had no effect on customer satisfaction. Customer satisfaction is influenced by factors such as call quality and customer engagement in membership card schemes (Ahn et al., 2006).

\section{Ho1: Customer satisfaction is unaffected by the efficiency of the company.}

Service of the Organization- When an organization runs with its successfulness, it seems that services quality is well-appointed (Gunarathne, 2014). According to Arslan, Iftikhar, and Zaman (2015), the service quality 
dimensions of efficiency and empathy affect customer satisfaction percentages. According to Chakraborty \& Mazumdar (2014), India's perceived after-sales service quality is low. Customers who are happy with a brand may not select the same brand for their next purchase, and responsibility, reliability, and empathy are important factors to consider. According to Hafez \& Akther (2017), service quality, customer satisfaction, confidence, and corporate image all have some relationship with customer loyalty but switching costs do not. In Ghana's mobile telecom industry, a study by Nimako (2012) found that tangibles, customer relations, real network quality, and image quality aspects of service quality positively affect customer satisfaction, which in turn affects behavior intention. Customers' perceived quality level and customer satisfaction are related, according to Omotayo \& Joachim (2008). According to Loke et al., (2011), consumer satisfaction and loyalty is greatly affected by efficiency, responsiveness, assurance, and empathy. According to Ocloo \& Tsetse (2013), there is a connection between quality service and satisfaction, and customer satisfaction has a significant impact on customer retention.

\section{Ho2: Services of the organization has no significant impact on customer satisfaction.}

Competency of the Organization- Customer satisfaction is largely determined by network efficiency. Poor network coverage can result in lower customer satisfaction with cell phone operators, which can lead to a rise in the number of complaints filed against them (Chen et al., 2011). Customer loyalty is unaffected by network reach, cost, offering, customer demand fulfillment, value added support, brand value, and the operator's contribution to society (Rahman, 2014). Cheng, Lai \& Yeung (2008) considered that customers find it difficult to determine the latter due to the presence of various characteristics of service, since service is one that cannot be sensed or touched like a commodity but can only be analyzed based on the attitude of the people (employee and customer) involved during the service transaction. According to Silva \&Yapa (2009), the popular assumption that price or low cost is the most important factor in determining consumer loyalty is incorrect; value addition to the customer is the most important factor. Many factors influence customer satisfaction, according to Khan \& Afsheen (2012), but price fairness (most important), coverage (second most important), and customer service (third most important) are three major factors that can have a significant impact on customer satisfaction. Kabir et al., (2009) collected data about customer expectations to determine the relationship between service quality and customer satisfaction, as well as service quality, switching cost, and confidence with customer loyalty. It has been discovered that it's the most accurate indicator of consumer loyalty. According to Negi (2009) and Rahman (2014) network efficiency is one of the important factors in measuring service quality and assessing overall customer satisfaction.

Ho3: Competency of the organization has no significant impact on customer satisfaction.

Product Price- Price, according to Zeithaml (1988), is what is lost or given up receiving a good or service. According to Bei \& Chiao (2001), price is defined as what is given up or lost to obtain a service or product, while Kotler \& Armstrong (2012) believe that price is defined as the amount of money paid for a product or service; the sum of the values that consumers exchange for the benefits of owning or using a product or service. Price can be used as a weapon to improve profit and customer satisfaction, according to Ehsani \& Ehsani (2015). Miah et al., (2018) explored the various components which influence consumer loyalty, or which can build consumer loyalty, for example, factors like price, quality in service, and brand reputation. According to Paulrajan and Rajkumar (2011), the most influential and preferential factors in selecting a telecommunication service provider were communication and price. Customer satisfaction is linked to brand image, service quality, and price, according to Malik et al., (2012).

Ho4: Product price range of the organization has no significant impact oncustomer satisfaction. 


\section{Conceptual Framework}

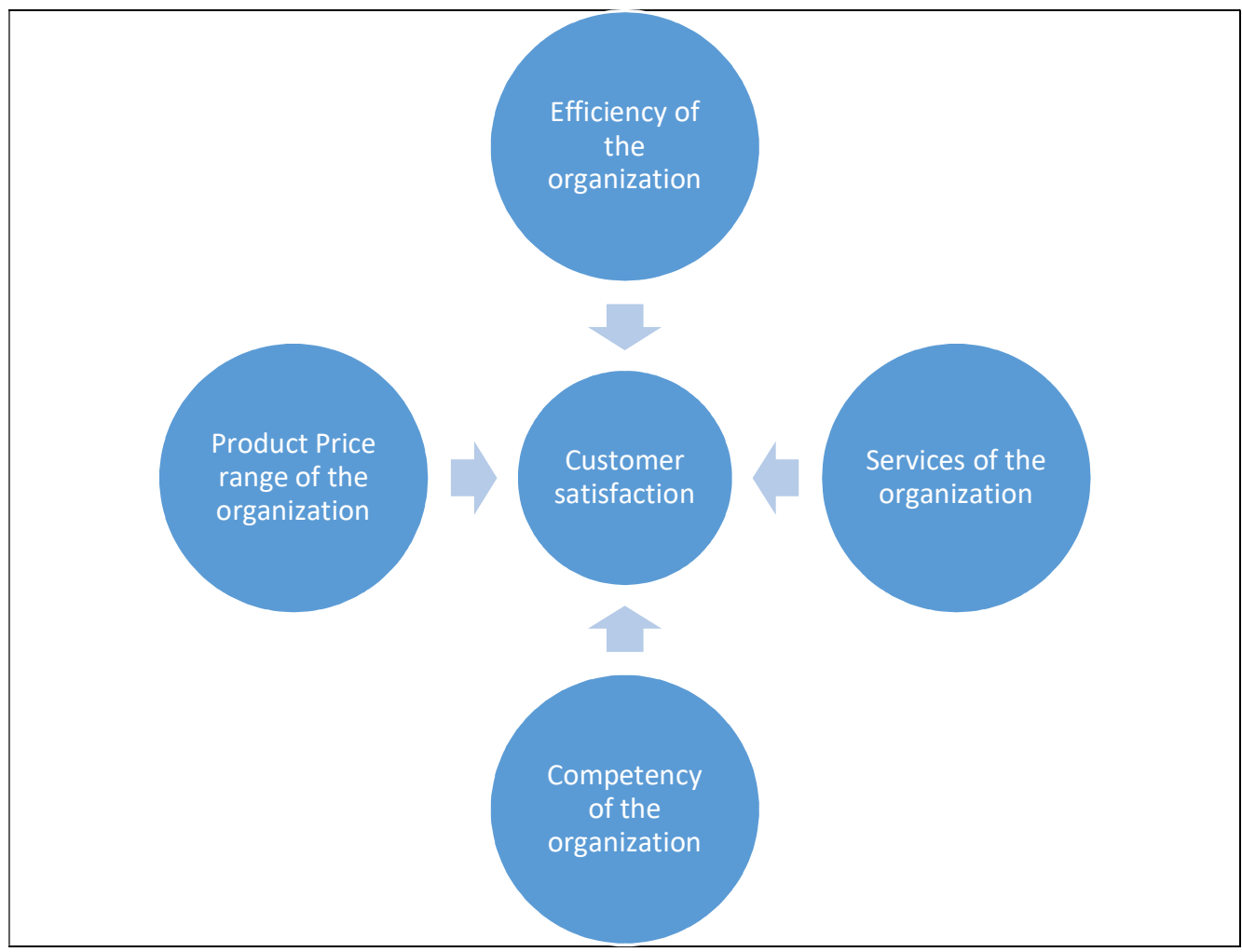

Figure 1: Conceptual Framework for this study

\section{Research Methodology:}

Both primary and secondary data were collected for the purpose of the study. The study was followed a quantitative approach to achieve the objectives of this study, which was descriptive in nature. For collecting the primary data, the researcher was selected the following methods: i) the interview method and ii) the observation method. A structured questionnaire with five-point Likert scale was used in the survey. For collecting data, Simple random sampling has been used. The Fisher formula (Fisher et al., 1983) has been used in determining the minimum sample size. The researcher surveyed 400 questionnaires from three companies like: Grameenphone, Banglalink and Robi/Airtel. All types of data were processed through computer-based Statistical Package for Social Science (SPSS) developed by Nieet al., (1975) and Smart PLS 3.2.3 technique was used for analyzing the data. Some statistical tools such as descriptive statistics, reliability analysis, validity analysis, cross loadings, collinearity statistics (VIF) and hypothesis testing were used to achieve the objectives of the study.

\section{Results \& Discussion:}

Table 1 below illustrates the demographic profile of the respondents which is demarcated according to their age, gender, profession, telecom partner and education.

Table 2 shows that out of 400 respondents 11 $(2.8 \%)$ respondents are very dissatisfied, 18 $(4.5 \%)$ respondents are dissatisfied, 114 $(28.5 \%)$ respondents are not decided about satisfaction or dissatisfaction, 248 (62\%) respondents are very satisfied, and rest 9 $(2.3 \%)$ respondents are very satisfied.

Reliability and Validity -To judge the internal reliability of the measurement instrument Cronbach's Alpha was utilized for the research smart PLS (partial least square) structural equation modelling technique has been used. A Cronbach's Alpha of 0.60 or higher is considered acceptable (Sekrran, 2003). For exploratory research composite reliability (CR) values of 0.60 to 0.70 are acceptable. But in case of advanced research, values between 
0.70 and 0.90 can be satisfactory (Hair et al., 2014).

Table 3 illustrates that the value of Cronbach's Alphas ( $\alpha)$ of Competency of the organization is 0.789 , Efficiency of the organization is 0.620 , Product price range of the organization is 0.617 and Services of the organization $r$ is 0.60 . Both values ensured the reliability of the survey questionnaire.

Table 1: Respondents' Demographic Profile

\begin{tabular}{|l|l|c|c|}
\hline Subject & Subgroup & Frequency & Percent \\
\hline \multirow{5}{*}{ Age } & 21 Years To 30 Years & 6 & 1.5 \\
\cline { 2 - 4 } & 31 Years To 34 Years & 144 & 36.0 \\
\cline { 2 - 4 } & 41 Years To 50 Years & 153 & 38.3 \\
\cline { 2 - 4 } & 51 Years To 60 Years & 83 & 20.8 \\
\cline { 2 - 4 } & 61 Years to Above & 14 & 3.5 \\
\hline \multirow{5}{*}{ Pex } & Male & 343 & 14.3 \\
\cline { 2 - 4 } & Female & 57 & 25.0 \\
\hline \multirow{5}{*}{ Telecom operator } & Job holder & 100 & 25.0 \\
\cline { 2 - 4 } & Businessman & 100 & 25.0 \\
\cline { 2 - 4 } & Farmer & 100 & 25.0 \\
\cline { 2 - 4 } & Student & 100 & 33.5 \\
\cline { 2 - 4 } & Grameenphone & 134 & 33.3 \\
\cline { 2 - 4 } & Banglalink & 133 & 33.3 \\
\hline \multirow{5}{*}{ Education } & Robi/Airtel & 133 & 15.0 \\
\cline { 2 - 4 } & Illiterate & 60 & 33.5 \\
\cline { 2 - 4 } & Below secondary & 134 & 31.3 \\
\cline { 2 - 4 } & Secondary to higher secondary & 47 & 8.5 \\
\cline { 2 - 4 } & Graduation & 125 & 34 \\
\cline { 2 - 4 } & Post-graduation & & \\
\hline
\end{tabular}

Source: Field Survey

Table 2: Overall Customer Satisfaction

\begin{tabular}{|l|c|c|}
\hline Satisfaction level & Frequency & Percent \\
\hline Very Dissatisfied & 11 & 2.8 \\
\hline Dissatisfied & 18 & 4.5 \\
\hline Neither satisfied nor dissatisfied & 114 & 28.5 \\
\hline Satisfied & 248 & 62.0 \\
\hline very satisfied & 9 & 2.3 \\
\hline Total & 400 & 100.0 \\
\hline
\end{tabular}

Source: Field Survey

Table 3: Cronbach's Alpha, Composite Reliability and Average Variance Extracted (AVE)

\begin{tabular}{|l|c|c|c|c|}
\hline Variable & $\begin{array}{c}\text { Cronbach's } \\
\text { Alpha }\end{array}$ & rho_A & $\begin{array}{c}\text { Composite } \\
\text { Reliability }\end{array}$ & $\begin{array}{c}\text { Average Variance } \\
\text { Extracted (AVE) }\end{array}$ \\
\hline $\begin{array}{l}\text { Competency of the } \\
\text { organization }\end{array}$ & 0.789 & 0.800 & 0.904 & 0.825 \\
\hline $\begin{array}{l}\text { Efficiency of the } \\
\text { organization }\end{array}$ & 0.620 & 0.909 & 0.821 & 0.700 \\
\hline $\begin{array}{l}\text { Product price range of the } \\
\text { organization }\end{array}$ & 0.617 & 0.846 & 0.823 & 0.703 \\
\hline $\begin{array}{l}\text { Services of the } \\
\text { organization }\end{array}$ & 0.600 & 0.632 & 0.811 & 0.685 \\
\hline
\end{tabular}


Kumar et.al.

Asia-Pacific J. Mgmt. Tech. Volume 1(4) 11-21

Table 4: Discriminant Validity

\begin{tabular}{|l|c|c|c|c|}
\hline Variable & $\begin{array}{c}\text { Competency } \\
\text { of the } \\
\text { organization }\end{array}$ & $\begin{array}{c}\text { Efficiency of } \\
\text { the } \\
\text { organization }\end{array}$ & $\begin{array}{c}\text { Price range of } \\
\text { the } \\
\text { organization }\end{array}$ & $\begin{array}{c}\text { Service of the } \\
\text { organization }\end{array}$ \\
\hline Competency of the organization & $\mathbf{0 . 9 0 0}$ & & & \\
\hline Efficiency of the organization & & 0.837 & & \\
\hline $\begin{array}{l}\text { Product price range of the } \\
\text { organization }\end{array}$ & & & 0.838 & \\
\hline Services of the organization & & & & 0.827 \\
\hline
\end{tabular}

The aim of the discriminant validity evaluation is to ensure that a reflective construct in the PLS path model has the best relationships with its own indicators (e.g., in comparison to any other construct) (Hair et al., 2017). In a simulation review, Henseler, Ringle, and Sarstedt (2015) found that approaches do not reliably detect the lack of discriminant validity in popular research situations. As a result, in variance-based structural equations modeling, comprehensive descriptions of the HTMT criterion for discriminant validity assessment are needed. They suggest evaluating discriminant validity using the HTMT criterion. If the HTMT value is less than 0.90 , discriminant validity between two reflective constructs has been identified (refer to table 4).

Confirmatory Factor Analysis (CFA)-The smart PLS (partial least square) structural equation modeling technique was used to develop CFA. When it comes to predicting and explaining target structures, the PLS-SEM method is useful (Hair et al., 2017).

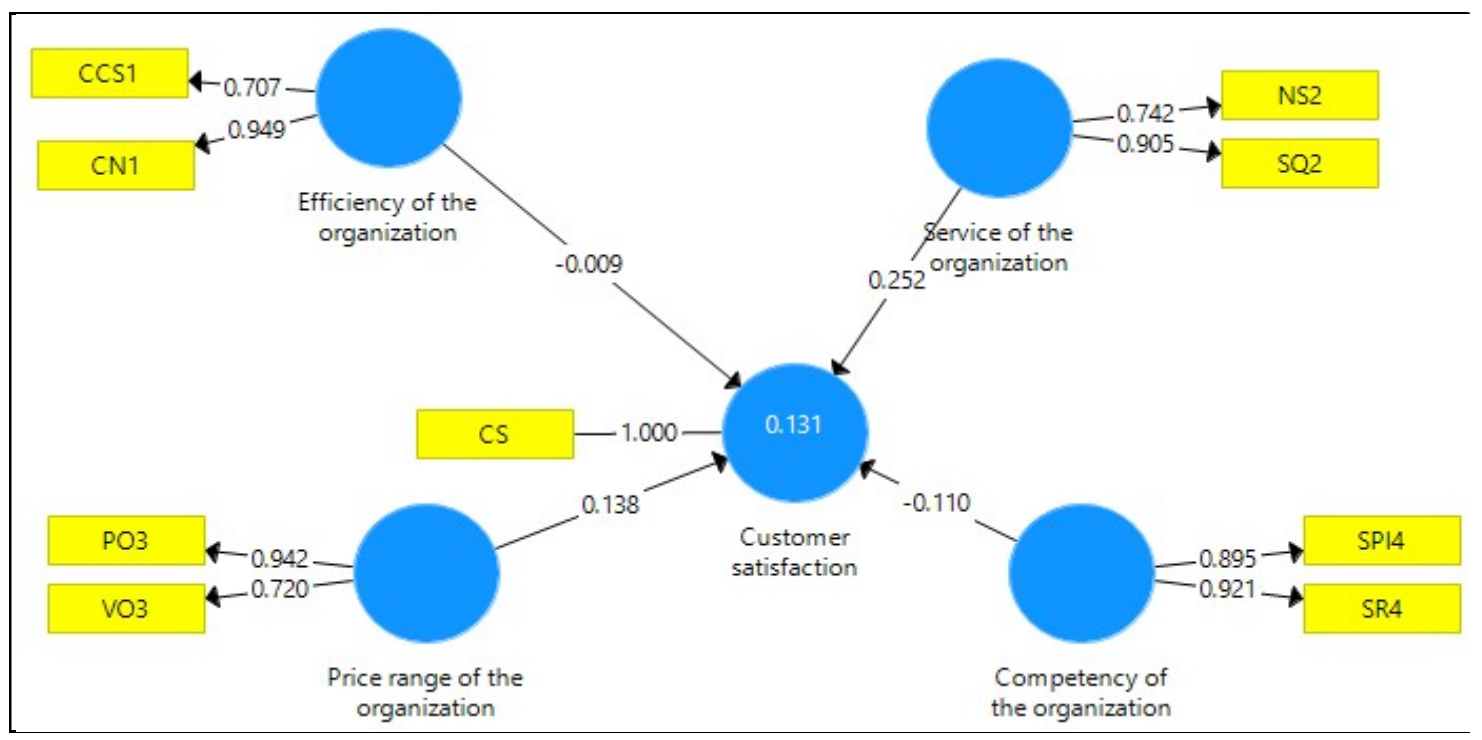

Figure 2: Confirmatory Factor Analysis (CFA)

Figure 2 shown that the latent variable efficiency of the organization consists of two independent factors customer care center service (CCS1) and connectivity and network (CN1). Latent variable services of the organization consist of two independent factors networking service (NS2) and service quality (SQ2). Latent variable competency of the organization consists of two independent factors secrecy of personal information (SPI4) and social responsibility (SR4). Latent variable product price range of the organization consists of two independent factors product offer (PO3) and variation of offer (VO3). The only dependent variable is customer satisfaction. All factor loadings are more than 0.70 .

\section{Calculation and Interpretation of $\mathbf{R}$ square value}

The smart PLS (partial least square) structural equation modeling technique was used to 
calculate R2. The R2 is a metric for determining a model's explanatory capacity (Shmueli\&Koppius, 2011). In-sample predictive strength is another name for the R2 (Rigdon, 2012). R2 is limited to a range of 0 to 1. A higher value means that the explanatory force is greater. The R2 value is represented in the table 5 below. It denotes a lack of explanatory capacity.

Table 5: R Square Value

\begin{tabular}{|c|c|c|}
\hline Subject & R Square & $\begin{array}{c}\text { R Square } \\
\text { Adjusted }\end{array}$ \\
\hline $\begin{array}{c}\text { Customer } \\
\text { satisfaction }\end{array}$ & 0.131 & 0.123 \\
\hline
\end{tabular}

Calculation and Interpretation of $F$ square value

The smart PLS (partial least square) structural equation modelling technique was used to calculate F2. Cohen's f2 (f-square) is used to assess the effect size of the predictor constructs: Cohen (1988) and (Hair et al., 2014) proposed different effect status based on F2 values. According to them, F2 values less than 0.02 indicate (no effect), 0.02-0.15 indicate (small effect), 0.15-0.35 indicate (medium effect), and F2 values greater than 0.35 indicate (large effect) (larger effect) (refer to table 6).

Table 6: F Square Value

\begin{tabular}{|l|c|c|}
\hline Variable & $\begin{array}{c}\text { Customer } \\
\text { satisfaction }\end{array}$ & Comment \\
\hline $\begin{array}{l}\text { Competency of the } \\
\text { organization }\end{array}$ & 0.005 & no effect \\
\hline $\begin{array}{l}\text { Efficiency of the } \\
\text { organization }\end{array}$ & 0.000 & no effect \\
\hline $\begin{array}{l}\text { Product price range } \\
\text { of the organization }\end{array}$ & 0.019 & $\begin{array}{c}0.02-0.15 \\
\text { (small effect) }\end{array}$ \\
\hline $\begin{array}{l}\text { Services of the } \\
\text { organization }\end{array}$ & 0.060 & $\begin{array}{c}0.02-0.15 \\
\text { (small effect) }\end{array}$ \\
\hline
\end{tabular}

\section{Collinearity Statistics (VIF)}

In the first phase of the structural equation model, lateral collinearity was calculated using the collinearity statistics 'variance inflation factor' (VIF). Even if vertical collinearity is satisfied, lateral collinearity (predictor-criterion collinearity) can often mislead the results. Collinearity occurs when two variables that are thought to be causally related test the same construct. If VIF values of 3.3 or higher indicate a possible collinearity, the VIF values were used to test it (Diamantopoulos \& Siguaw, 2006). Table 7 shows the outputs of VIF values. The value means that there is not any collinearity. This form of collinearity is valued by the VIF.

Table 7: Collinearity Statistics (Outer VIF Values)

\begin{tabular}{|l|c|}
\hline \multicolumn{1}{|c|}{ Factor } & VIF \\
\hline $\begin{array}{l}\text { Customer care center service } \\
\text { (CCS1) }\end{array}$ & 1.252 \\
\hline Connectivity and network (CN1) & 1.252 \\
\hline Networking service (NS2) & 1.175 \\
\hline Product offer (PO3) & 1.248 \\
\hline $\begin{array}{l}\text { Secrecy of personal information } \\
\text { (SPI4) }\end{array}$ & 1.739 \\
\hline Service quality (SQ2) & 1.175 \\
\hline Social responsibility (SR4) & 1.739 \\
\hline Variation of offer (VO3) & 1.248 \\
\hline
\end{tabular}

\section{Test of Hypothesis}

The study hypotheses were tested using the bootstrapping protocol with a resample of 1000, as recommended by Hair et al., (2014). Table8 shows the path coefficients of the various constructs, as well as their significance levels.

Table 8: Results of Hypothesis Test (Ho1, Ho2, Ho3 and Ho4)

\begin{tabular}{|l|c|}
\hline Subject & $\begin{array}{c}\boldsymbol{P} \\
\text { Values }\end{array}$ \\
\hline $\begin{array}{l}\text { Ho1: Efficiency of the organization -> } \\
\text { Customer satisfaction }\end{array}$ & 0.899 \\
\hline $\begin{array}{l}\text { Ho2: Services of the organization -> } \\
\text { Customer satisfaction }\end{array}$ & 0.000 \\
\hline $\begin{array}{l}\text { Ho3: Competency of the organization } \\
->\text { Customer satisfaction }\end{array}$ & 0.157 \\
\hline $\begin{array}{l}\text { H04: Product price range of the } \\
\text { organization -> Customer satisfaction }\end{array}$ & 0.010 \\
\hline
\end{tabular}

Table 8 depicts the impact of efficiency of the organization to customer satisfaction is supported by Ho1: $(t=0.126, p<0.899)$. In this case the result indicates accepting of null hypothesis. It designates no significant impact of efficiency of the organization to customer satisfaction. The impact of services of the organization to customer satisfaction is supported by Ho2: $(t=4.810, p<0.0001)$. In this case the result indicates rejecting of null hypothesis. It designates presence of significant impact of services of the organization to customer satisfaction. The impact of competency of the organization to customer satisfaction is supported by Ho3: $(\mathrm{t}=$ $1.415, p<0.157)$. The result supports accepting of null hypothesis. It denotes that there exists no significant impact of competency of the organization to customer satisfaction. The impact of product price of the organization to customer satisfaction is supported by Ho4: $(t=$ 
2.587, p<0.010). In this case the result indicates rejecting of null hypothesis. It designates presence of significant impact of product price of the organization to customer satisfaction.

\section{Conclusion:}

From the observation of this research it can be seen that adulthood and illiterate personality has no feelings and considering service offer, price, internet facilities etc. They need good network and talk time service. Educated personality and young-aged people are very conscious about talk time, network, service quality, internet facility, product offer etc. The study revealed that there is a major relationship between customer care center service, connectivity and network, networking service, service quality, secrecy of non-public information, social responsibility, product offer and variation of offer on customer satisfaction. The study also finds that product price and repair quality have a major impact on customer satisfaction of telecom sector in Bangladesh.

\section{Recommendation:}

All telecommunication company should increase the standard of network throughout the country to capture the utmost users. Call rate should be considered by all the operators. Customers want comparatively low call rate from the operators. Customer care service should be increased to the local area and services provided by the customer care person should be mannered. Customer care service over the phone should be easy to access with the users. Different messaging services provided by the operators should be reviewed. Internet speed of the operators should be increased to satisfy customer and to carry the customer otherwise users switch the operator; especially the scholars try this. Internet package rate is additionally considering factor to draw in customers to prevent the switching by the user, company should provide a competitive internet package rate to carry the present customers and to draw in the opposite operator customers. Company providing calls should be stopped though it provides offer and other promotions because the users are not always in good mood during a critical moment.
All the operators should keep in mind that Mobile Number Portability (MNP) service are available in Bangladesh. Therefore, the users can easily switch the operator without changing number. For this reason, all the operators should provide competitive services to exist within the Bangladeshi telecommunication market.

\section{Acknowledgments:}

The authors are thankful to the institutional authority for completion of the work.

\section{Conflicts of Interest:}

The authors declare that the research review was conducted in the absence of any commercial or economic associations that could be construed as a potential conflict of interest.

\section{References}

Ahn, J., Han, S. \& Lee, Y. (2006) Customer Churn Analysis: Churn Determinants and Mediation Effects of Partial Defection in the Korean Mobile Telecommunications Service Industry. Elsevier Telecommunications Policy, 30, 552-568.

Alam, M. M. D. \& Noor, N. A. M. (2020). The relationship between service quality, corporate image, and customer loyalty of Generation Y: An application of SOR paradigm in the context of superstores in Bangladesh. SAGE Open, 10(2), 2158244020924405.

Agbor, J. M. (2011). The Relationship between Customer Satisfaction and Service Quality: a study of three Service sectors in Umeå. http://umu.diva-portal.org/smash/get/

diva2:448657/FULLTEXT02.pdf

Arslan, M., Iftikhar, M. \& Zaman, R. (2015) Effect of Service Quality Dimensions on Customer Satisfaction: A Comparative Analysis of Pakistan Telecom Sector. British Journal of Marketing Studies, 3(6), 43-62.

Bala, T., Hossain, I. \& Mondal, D. A. G. R. (2018). Measurement of Customer Satisfaction of Different Mobile Operators in Bangladesh: A Study on Bangabandhu Sheikh Mujibur Rahman Science and Technology University, Gopalganj, Bangladesh. OSR Journal of 
Business and Management (IOSRJBM), 20(3), 38-47.

Bei, L.T. \&Chiao, Y.C., 2001. An Integrated Model for the Effects of Perceived Product, Perceived Service Quality, and Perceived Price Fairness on Consumer Satisfaction and Loyalty. Journal of Consumer Satisfaction, Dissatisfaction and Complaining Behavior. 14, 125-140.

BTRC. (2020). Report Bulletin, Dhaka: Bangladesh Telecommunication Regulatory. www.btrc.gov.bd.

Chakraborty, O. \& Mazumdar, S. (2014). Impact of the Consumers' Service Satisfaction on Brand Loyalty with Reference to Indian Telecom Industry, International Journal of Applied Services Marketing Perspectives, 3(4), 1321.

Chen, A., Zhang, H., Cai, W., Lan, K. \& Wang, H. (2011, November). The causes of customer satisfaction in telecommunication service: an empirical study. In 2011 7th International Conference on Advanced Information Management and Service (ICIPM) (pp. 129132). IEEE.

Cheng, T., Lai, L. \& Yeung, A. (2008). The Driving Forces of Customer Loyalty: A Study of Internet Service Providers in Hong Kong. International Journal of E-Business Research, 4(4), 26-42.

Cohen, J. (1988). Statistical Power Analysis for the Behavioral Sciences. Hillsdale, NJ: Erlbaum.

Danish, R.Q., Ahmad, F., Ateeq, A., Ali, H.Y. \&Humayon, A.A. (2015). Factors Affecting Customer Retention in Telecom Sector of Pakistan. American Journal of Marketing Research, 1(2), 28-36.

Dhaka Tribune (June 19, 2020). BTRC: Mobile phone subscribers reach $162.9 \mathrm{~m}$ in April. Dhaka Tribune.

https://www.dhakatribune.com/bangladesh/dh aka/2020/06/19/btrc-mobile-phonesubscribers-reach-162-9m-in-April.

Diamantopoulos, A. \&Siguaw, J.A. (2006). Formative versus Reflective Indicators in Organizational Measure Development: A
Comparison and Empirical Illustration. British Journal of Management, 17(4), 263-282.

Durdyev, S., Ihtiyar, A., Banaitis, A. \& Thurnell, D. (2018). The Construction Client Satisfaction Model: A PLS-SEM Approach. Journal of Civil Engineering and Management, 24(1), 31-42. ISSN1392-3730/elSSN1822-3605.

https://doi.org/10.3846/jcem.2018.297

Ehsani, Z. \&Ehsani, M.H. (2015). Effect of Quality and Price on Customer Satisfaction and Commitment in Iran Auto Industry. International Journal of Service Sciences, Management and Engineering. 1(5), 52-56.

Farris, P.W., Bendle, N.T., Pfeifer, P.E. \&Reibstein, D.J. (2010). Marketing Metrics: The Definitive Guide to Measuring Marketing Performance. Upper Saddle River, New Jersey: Pearson Education, Inc. ISBN 0-13705829-2.

Fisher, A., Laing, J. \&Stoeckel, J. (1983). Handbook for Family Planning Operations Research Design. Population Council.

Gunarathne, U. (2014). Service Quality and Customer Satisfaction in Sri Lankan Hotel Industry. International Journal of Scientific and Research Publications, 4(11), 1-8.

Hafez, M. \&Akther, N. (2017). Determinants of Customer Loyalty in Mobile Telecommunication Industry in Bangladesh. Global Journal of Management and Business Research, 17(1), 140-148.

Hair Jr, J. F., Sarstedt, M., Hopkins, L. \&Kuppelwieser, V. G. (2014). Partial least squares structural equation modeling (PLSSEM): An emerging tool in business research. European Business Review, 26(2), 106-121.

Hair, J.F., Hult, G.T.M., Ringle, C.M. \&Sarstedt, M. (2017). A Primer on Partial Least Squares Structural Equation Modeling (PLS-SEM)., 2nd Ed., Thousand Oakes, CA: Sage.

Henseler, J., Ringle, C.M. \&Sarstedt, M. (2015). A New Criterion for Assessing Discriminant Validity in Variance-based Structural Equation Modeling., Journal of the 
Academy of Marketing Science, 43(1), 115135.

Hossain, M.S., Hossain, M.A. \&Siddikee, M.J. (2012). The Drivers of Customers' Satisfaction of Airtel Bangladesh Limited. Bangladesh Research Publications Journal, 7(4), 437-445.

Hossain, A., Sultana, J. \&Mazmum, F.A. (2016) Addressing the Factors Influencing Customer Satisfaction of 3G Mobile Phone Services: A Case of Dhaka City, Bangladesh. Global Journal of Management and Business Research, 16 (2), 8-16.

Irfan, M., Shamsudin, M.F. \&Hadi, N.U. (2016). How important is Customer Satisfaction? Quantitative Evidence from Mobile Telecommunication Market. International Journal of Business and Management, 11(6), 57-69.

Kabir, M. R., Alam, M. M. D. \&Alam, Z. (2009). Factors determining the customer satisfaction \& loyalty: A study of mobile telecommunication industry in Bangladesh. ASA University Review, 3(2), 147-156.

Khan, S. \&Afsheen, S. (2012) Determinants of Customer Satisfaction in Telecom Industry a Study of Telecom industry Peshawar KPK Pakistan. Journal of Basic and Applied Scientific Research, 2 (12), 12833-12840.

Kim, M., Park, M. \&Jeong, D. (2004) The Effects of Customer Satisfaction and Switching Barrier on Customer Loyalty in Korean Mobile Telecommunication Services. Telecommunications Policy, 28 (2004), 145159.

Kotler, P. \&Amstrong, G. (2012). Principle of Marketing.14th Edition. New Jersey. Published by Prentice Hall.

Kumar, D., Mukherjee, S., Haque, A. \& Anis, Z. (2020). Measuring Student Satisfaction towards Mobile Service Provider in Bangladesh: With Special Reference to Grameen Phone Limited. Journal of Xidian University, 14(5), 184-200.

Loke, S. P., Taiwo, A. A., Salim, H. M., Downe, A. G. \& Petronas, U. T. (2011). Service quality and customer satisfaction in a telecommunication service provider. In International Conference on Financial
Management and Economics (Vol. 11, No. 2, pp. 23-29).

Malik, M.E., Ghafoor, M. \& Iqbal, H. K. (2012). Impact of Brand Image, Service Quality and Price on Customer Satisfaction in Pakistan Telecommunication Sector. International Journal of Business and Social Science, 3(23), 123-129.

Miah, I., Azad, A.K. \& Ferdous, J. (2018). Factors Influencing Customer Satisfaction on Local and Foreign Telecommunication Companies in Malaysia. International Journal of Scientific \& Engineering Research, 9(4), 1374-1413.

Mouri, N. (2005). An Examination of Consumer Value, Satisfaction and Postpurchase behavior. University of Central Florida, 156.

Negi, R. (2009). Determining Customer Satisfaction through Perceived Service Quality: A Study of Ethiopian Mobile Users. International Journal of Mobile Marketing, 4(1), 31-38.

Nimako, S.G. (2012). Linking Quality, Satisfaction and Behaviour Intentions in Ghana's Mobile Telecommunication Industry. European Journal of Business and Management, 4 (7), 1-17.

Nie, N. H., Bent, D. H. \& Hull, C. H. (1975). SPSS: Statistical Package for the Social Sciences (Vol. 227). New York: McGraw-Hill.

Nurysh, N., Naghavi, N. \& Fah, B.C.Y. (2019). Study on Factors Affecting Customer Satisfaction in Mobile Telecommunication Industry in Malaysia. International Journal of Recent Technology and Engineering (IJRTE), 7(5S), 299- 316.

Ocloo, C.E. \& Tsetse, E.K. (2013) Customer Retention in the Ghanaian Mobile Telecommunication Industry. European Journal of Business and Social Sciences, 2 (7), 136-160.

Omotayo, O. \& Joachim, A.A. (2008) Customer Service in the Retention of Mobile Phone Users in Nigeria. African Journal of Business Management, 2 (2), 26-31. 
Paulrajan, R. \& Rajkumar, H. (2011) Service Quality and Customers Preference of Cellular Mobile Service Providers. Journal of Technology Management \& Innovation, 6(1), 38-45.

Putri, W. K. \&Pujani, V. (2019). The influence of system quality, information quality, e-service quality and perceived value on Shopee consumer loyalty in Padang City. The International Technology Management Review, 8(1), 10-15.

$\begin{array}{llr}\begin{array}{l}\text { Rahman, H. (2014). } \\ \text { customer }\end{array} \text { Fatisfaction } & \begin{array}{c}\text { Factors } \\ \text { in }\end{array} & \begin{array}{r}\text { affecting } \\ \text { mobile }\end{array} \\ \text { telecommunication } & \text { industry } & \text { in } \\ \text { Bangladesh. Business, } & \text { Management and } \\ \text { Education, 12(1), 74-93. } & & \end{array}$

Rigdon, E.E. (2012). Rethinking Partial Least Squares Path Modeling: In Praise of Simple Methods. Long Range Planning, 45 (5/6), 341358.

Rizomyliotis, I., Konstantoulaki, K., Kaminakis, K., Giovanis, A. \&Papastathopoulos, A. (2018). Antecedents of Customer Loyalty in the Mobile Telecommunication Market: A Cross-Cultural Investigation. Academy of Marketing Studies Journal, 22(4), 1-10.
Sekaran, U. (2003). Research Method for Business: A Skill Building Approach. 7th Edition, John Wiley and Sons, New York; 2003.

Shmueli, G. \&Koppius, O.R. (2011). Predictive Analytics in Information Systems Research, MIS Quarterly, 35 (3), 553-572.

Silva, K.A. \&Yapa, S.T.W.S. (2009). Customer Retention: With Special Reference to Telecommunication Industry in Sri Lanka, Paper presented at International Conference on Business and Information, Kuala Lumpur, Malaysia, July 2009, 1- 15.

Uddin, M.R., Haque, M.E. \&Bristy, J.F. (2014). Customer Satisfaction of Telecom Industry in Khulna City, Bangladesh, European Journal of Business and Management, 6(23), 87-94.

Yeo, G.T., Vinh V. Thai, V.V. \&Roh, S.Y. (2015). An Analysis of Port Service Quality and Customer Satisfaction: The Case of Korean Container Ports. The Asian Journal of Shipping and Logistics, 31(4), 437-447.

Zeithaml, V.A. (1988). Consumer Perceptions of Price, Quality, and Value: A Means-End Model and Synthesis of Evidence. Journal of Marketing, 52, 2-22. 